\title{
Selenium-Enriched Probiotic Saccharomyces boulardii CCT 4308 Biomass Production Using Low-Cost Sugarcane Molasses Medium
}

\author{
Denise Honda Kitamura ${ }^{1}$ \\ https://orcid.org/0000-0002-5519-2682
}

Luciana Porto de Souza Vandenberghe ${ }^{1 *}$
https://orcid.org/0000-0003-0267-1185

Cristine Rodrigues ${ }^{1}$

https://orcid.org/0000-0002-0212-1143

\author{
Denise Naomi Xavier Salmon ${ }^{1}$ \\ https://orcid.org/0000-0002-9813-8133 \\ Gilberto Vinícius de Melo Pereira' \\ https://orcid.org/0000-0001-7671-8682 \\ Carlos Ricardo Soccol ${ }^{1}$ \\ https://orcid.org/0000-0001-7630-6864
}

${ }^{1}$ Federal University of Paraná, Bioprocess Engineering and Biotechnology Department, Curitiba, Paraná, Brazil.

Editor-in-Chief: Paulo Vitor Farago

Associate Editor: Luiz Gustavo Lacerda

Received: 2020.10.12; Accepted: 2021.02.24.

*Correspondence: Ivandenberghe@ufpr.br, Tel.: +55 4133613271 (L.P.S.V.).

\section{HIGHLIGHTS}

- Sugarcane molasses was an effective substrate for $S$. boulardii biomass production.

- S. boulardii cells efficiently accumulated selenium.

- Fed-batch operation led to higher S. boulardii biomass production.

- A new bioprocess was developed for Se-enriched S. boulardii biomass production.

Abstract: Food supplements have been increasingly investigated. Probiotics have several benefits for human and animal health and selenium (Se) is widely recommended against oxidative stress. In this context, the aim of this study was to develop a low-cost bioprocess to produce a functional food product comprising both probiotic and Se accumulation. Yeast cells of Saccharomyces boulardii CCT 4308 were cultivated using sugarcane molasses as substrate. Optimization studies were performed to evaluate the best medium composition for biomass production and Se-accumulation in batch and fed-batch systems. Optimized conditions were defined with a medium composed of $150 \mathrm{~g} \mathrm{~L}^{-1}$ sugarcane molasses and $12 \mathrm{~g} \mathrm{~L}^{-1}$ yeast extract, with feeding of $100 \mathrm{~g} \mathrm{~L}^{-1}$ sugarcane molasses and $100 \mu \mathrm{g} \mathrm{mL}^{-1}$ of Se incorporation after $4 \mathrm{~h}$ and $10 \mathrm{~h}$ of fermentation, respectively, during $48 \mathrm{~h}$ in STR (stirred tank reactor). Best biomass production reached 14.52 $\mathrm{g} \mathrm{L}^{-1}$ with $3.20 \mathrm{mg} \mathrm{Se} \mathrm{g}^{-1}$ biomass at $12 \mathrm{~h}$. Process optimization led to 4.82 -fold increase in biomass production compared to initial condition. A final Se-enriched S. boulardii CCT 4308 biomass was obtained, which is comparable to commercial products. An alternative probiotic yeast biomass was efficiently produced as a new food-form of Se supplement in a sustainable process using an inexpensive agro-industrial residue.

Keywords: selenium; Saccharomyces boulardii; probiotic; fed-batch culture; sugarcane molasses. 


\section{GRAPHICAL ABSTRACT}
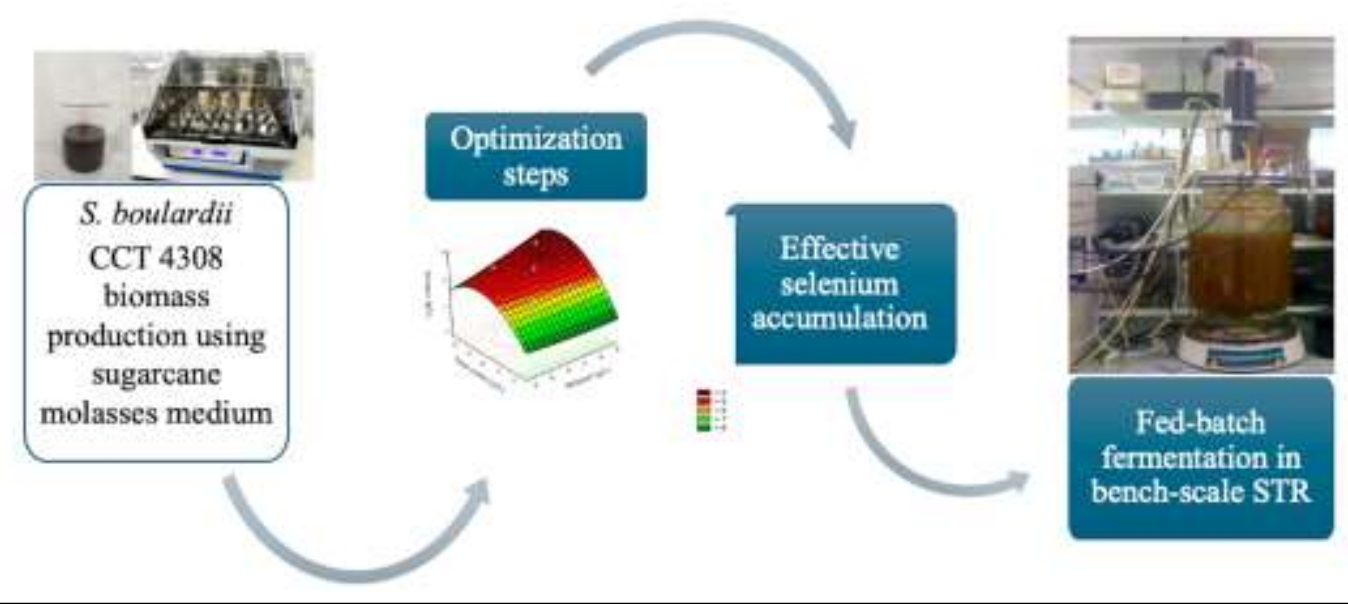

\section{INTRODUCTION}

Probiotics are supplements based on living microorganisms that aim health benefits for human and animals when consumed in adequate amounts [1,2]. Scientific researches show that these nutritional supplements demonstrate multiple properties, which are helpful to natural intestinal microbiota equilibrium [1], present anti-inflammatory and anti-allergenic properties [3] and improvement of immunity [4]. Most probiotic microorganism sources are bacteria, especially lactic acid bacteria [2], although some yeasts such as Saccharomyces cerevisiae and Saccharomyces boulardii have been increasingly applied to this purpose $[5,6]$. The advantages of yeasts as probiotic are due to its high resistance to lyophilization process, easy disposal after discontinuation of therapy and are not affected by the use of antibiotics. While probiotics improve life quality, selenium (Se) is an essential trace element for growth and development of humans and animals [7]. It is highly recommended as a food supplement because it protects tissues from oxidative stress [8], a significant role in cancer prevention [9], maintenance of defenses against infections [8], and metabolic disorders including diabetes [10]. Besides that, Se is widely applied on nutritional quality of sprouts and microgreens [11], cattle and pigs health [12].

In order to produce natural nutritional supplements by microorganisms enriched with essential minerals, such as selenium, copper and zinc, many studies have been reported about cultivation parameters of yeast strains and mushrooms [5,7,13]. In appropriate culture conditions, yeasts are able to accumulate great amounts of Se, incorporating as organic Se, mostly selenomethionine, which is the best Se source for humans and animals [1,14]. A new strategy is needed, combining the health efficiency of probiotic from $S$. boulardii and Se supplementation in a single product. Its profile, which includes non-pathogenic and probiotic characteristics [15,16] and resistance to the gastrointestinal tract [17], becomes $S$. boulardii a great candidate for this purpose. This yeast is already widely prescribed in several countries in lyophilized form as a preventive and therapeutic agent for diarrhea and gastrointestinal disorders $[2,18]$. The industrial production of Se-enriched yeast biomass is far more versatile than Se-enriched in plants [19] and follows the convenient process of yeast production: easy separation, fast cell growth and a wide range of alternative substrates. These factors lead to increasing interest in the bioprocess development with maximum inorganic Se conversion and, thus, its incorporation by yeasts [20].

Another aspect, agro-industrial residues [21,22] are widely employed as potential substrates in bioprocesses to produce high-value compounds. Sugarcane molasses is dark, viscous and sugar rich byproduct of sugar extraction from sugarcane [23]. Sugarcane molasses contains approximately $34 \%$ of sucrose, reducing sugars (glucose and fructose) and several minerals [23]. Annually, it is estimated that about 10 million tons of sugarcane molasses are discharged, becoming it an available raw material with high nutritional composition for low-cost fermentation processes [24].

Therefore, the aim of this study is the optimization of $S$. boulardii CCT 4308 Se-rich probiotic biomass production using sugarcane molasses agro-residue as a carbon source. Batch and fed-batch processes were tested, including media composition and fermentation parameters. The best conditions were then evaluated for biomass Se accumulation to obtain a probiotic Se-enriched yeast product. 


\section{MATERIAL AND METHODS}

\section{Microorganism and inoculum preparation}

Saccharomyces boulardii CCT 4308, reference UFPEDA 1176, current name Saccharomyces cerevisiae Meyen ex E.C. Hansen 1883, was obtained from Tropical Culture Collection (CCT) of André Tosello Foundation (Campinas-SP, Brazil). Sugarcane molasses was donated by Ourofino Agronegócio (Ribeirão Preto-SP, Brazil). S. boulardii CCT 4308 was grown aerobically in $125 \mathrm{~mL}$ Erlenmeyer flasks containing 50 $\mathrm{mL}$ of yeast-malt extract broth (YMB), which was composed of $\left(\mathrm{g} \mathrm{L}^{-1}\right)$ : peptic digest of animal tissue, 5.0; yeast extract, 3.0; malt extract, 3.0 and dextrose, 10.0, distilled water and $\mathrm{pH}$ was adjusted to 5.5. Flasks were incubated at $30^{\circ} \mathrm{C}$ in a rotatory shaker at $120 \mathrm{rpm}$ for $20 \mathrm{~h}$. The obtained culture was used for inoculation as inoculum at $10 \%(\mathrm{v} / \mathrm{v})$ in further experiments. S. boulardii CCT 4308 was kept on slanted YMB solid medium at $4^{\circ} \mathrm{C}$, it was transferred to a new $\mathrm{YMB}$ solid medium each 2 weeks and it was incubated at $30^{\circ} \mathrm{C}$ for $48 \mathrm{~h}$ to maintain viability. The strain was maintained in $\mathrm{YMB}$ medium with glycerol, stored at $-80^{\circ} \mathrm{C}$ and liquid nitrogen at $-196^{\circ} \mathrm{C}$.

\section{Optimization of medium composition for Saccharomyces boulardii CCT 4308 biomass production}

The first trial of experiments was carried out with the support of a Plackett-Burman design (P\&B), with eleven factors (sugarcane molasses, glucose, yeast extract, $\left(\mathrm{NH}_{4}\right)_{2} \mathrm{HPO}_{4}, \mathrm{MgSO}_{4} \cdot 7 \mathrm{H}_{2} \mathrm{O}, \mathrm{K}_{2} \mathrm{HPO}_{4}, \mathrm{KH}_{2} \mathrm{PO}_{4}$, $\left.\mathrm{ZnSO}_{4} \cdot 7 \mathrm{H}_{2} \mathrm{O}, \mathrm{FeSO}_{4} \cdot 7 \mathrm{H}_{2} \mathrm{O}, \mathrm{CuSO}_{4} \cdot 5 \mathrm{H}_{2} \mathrm{O}, \mathrm{MnSO}_{4} \cdot \mathrm{H}_{2} \mathrm{O}\right)$. Each factor was studied in two levels, presence $(+1)$ and absence (-1) (Table 1), and 3 central points corresponding to 19 experiments. This study was performed in order to screen the significant factors that influence $S$. boulardii CCT 4308 biomass production. The concentration of each component was determined based on S. cerevisiae biomass production studies [25].

Table 1. Study of the influence of medium composition on S. boulardii CCT 4308 biomass production through P\&B design.

\begin{tabular}{lccc} 
Variables $\left(\mathbf{g ~ L}^{-1}\right)$ & \multicolumn{3}{c}{ Levels } \\
\hline & $-\mathbf{1}$ & $\mathbf{0}$ & $\mathbf{+ 1}$ \\
\hline Glucose & 0 & 16.0 & 32.0 \\
\hline Sugarcane molasses & 0 & 10.0 & 20.0 \\
\hline Yeast extract & 0 & 7.5 & 15.0 \\
\hline$\left(\mathrm{NH}_{4}\right)_{2} \mathrm{HPO}_{4}$ & 0 & 4.0 & 8.0 \\
\hline $\mathrm{MgSO}_{4} \cdot 7 \mathrm{H}_{2} \mathrm{O}$ & 0 & 2.5 & 5.0 \\
\hline $\mathrm{K}_{2} \mathrm{HPO}_{4}$, & 0 & 0.5 & 1.0 \\
\hline $\mathrm{KH}_{2} \mathrm{PO}_{4}$ & 0 & 0.5 & 1.0 \\
\hline $\mathrm{ZnSO}_{4} \cdot 7 \mathrm{H}_{2} \mathrm{O}$ & 0 & 0.005 & 0.01 \\
\hline $\mathrm{FeSO}_{4} \cdot 7 \mathrm{H}_{2} \mathrm{O}$ & 0 & 0.003 & 0.006 \\
\hline $\mathrm{CuSO}_{4} \cdot 5 \mathrm{H}_{2} \mathrm{O}$ & 0 & 0.003 & 0.006 \\
\hline $\mathrm{MnSO}_{4} \cdot \mathrm{H}_{2} \mathrm{O}$ & 0 & 0.003 & 0.006 \\
\hline
\end{tabular}

A second set of experiments was conducted with the use of a $2^{3}$ CCRD (central composite rotational design) consisting of three independent variables at three levels $(-1,0$ and +1$), 3$ central points and 6 axial points $(-1.68$ and +1.68$)$, with 17 experiments. Independent variables $\left(\mathrm{g} \mathrm{L}^{-1}\right)$ were: glucose $(38.64,40.0,42.0$, 44.0 and 45.36), sugarcane molasses $(36.59,40.0,45.0,50.0$ and 53.41) and yeast extract (1.59, 5.0, 10.0, 15.0 and 18.41). Response surface methodology was used to evaluate the best C:N ratio for $S$. boulardii CCT 4308 biomass production. Optimization experiments were carried out in $125 \mathrm{~mL}$ Erlenmeyer flasks containing $50 \mathrm{~mL}$ of culture medium and inoculated at $10 \%(\mathrm{v} / \mathrm{v})$. Flasks were incubated at $30^{\circ} \mathrm{C}$ in a rotatory shaker at $120 \mathrm{rpm}$ for $48 \mathrm{~h}$. YMB medium was used as a control for S. boulardii CCT 4308 growth evaluation. 


\section{Statistical analysis}

All optimization steps were defined and analyzed using the STATISTICA ${ }^{\circledR}$ software version 5.0 (StatSoft Inc., Tulsa, OK, USA). Data were analyzed by ANOVA and Tukey's Pairwise Comparisons using GraphPad PRISM 3.0 software. Complementary experiments (in triplicate) were performed using the optimized conditions to validate results.

\section{Effect of sugarcane molasses as sole carbon source on Saccharomyces boulardii CCT 4308 biomass production}

Different sugarcane molasses concentrations were evaluated to replace glucose in the culture medium, in order to use it as a potential carbon source to reduce biomass production costs. Three sugarcane molasses concentrations $\left(100,150\right.$, and $\left.200 \mathrm{~g} \mathrm{~L}^{-1}\right)$ were tested and yeast extract at $12 \mathrm{~g} \mathrm{~L}^{-1}$. Biomass production was carried out in $125 \mathrm{~mL}$ Erlenmeyer flasks containing $50 \mathrm{~mL}$ of culture medium according to each condition. Flasks were incubated at $30^{\circ} \mathrm{C}$ in a rotatory shaker at $120 \mathrm{rpm}$ for $48 \mathrm{~h}$. YMB medium was used as a control (without sugarcane molasses) for $S$. boulardii CCT 4308 growth evaluation. Essays were conducted in triplicate.

\section{Batch and fed-batch fermentation for biomass production by Saccharomyces boulardii CCT 4308}

Biomass production was carried out under optimized conditions in Erlenmeyer flasks and STR in batch and fed-batch operation. Kinetics of $S$. boulardii CCT 4308 biomass production was first performed in batch fermentation. $125 \mathrm{~mL}$ Erlenmeyer flasks containing $50 \mathrm{~mL}$ of optimized culture medium $\left(150 \mathrm{~g} \mathrm{~L}^{-1}\right.$ sugarcane molasses and $12 \mathrm{~g} \mathrm{~L}^{-1}$ yeast extract) were incubated at $30^{\circ} \mathrm{C}$ in a rotatory shaker at $120 \mathrm{rpm}$. Samples were withdrawn each $8 \mathrm{~h}$ during $56 \mathrm{~h}$ of fermentation. Fermentation was also conducted in a $14 \mathrm{~L} \mathrm{STR}$ (Bioflo ${ }^{\circledR}$ 110; New Brunswick) using a working volume of $9 \mathrm{~L}$. Temperature, $\mathrm{pH}$, aeration, $\mathrm{dO}_{2}$ and agitation were controlled $\left(30^{\circ} \mathrm{C}, \mathrm{pH} 5.5,1 \mathrm{vvm}, 30 \%, 300 \mathrm{rpm}\right.$, respectively). Samples were withdrawn each $2 \mathrm{~h}(0-16 \mathrm{~h}), 8$ $\mathrm{h}(16-24 \mathrm{~h}), 4 \mathrm{~h}(24-32 \mathrm{~h})$ and $16 \mathrm{~h}$ (48h) during $48 \mathrm{~h}$. A fed-batch strategy was studied since almost complete total sugars consumption occurred after $8 \mathrm{~h}$ of fermentation. Fed-batch fermentation was conducted under the same conditions as batch fermentation in Erlenmeyer flasks. Feeding of $100 \mathrm{~g} \mathrm{~L}^{-1}$ sugarcane molasses was evaluated at 4 and $6 \mathrm{~h}$ in a total of $10 \mathrm{~h}$ of fed-batch fermentation. A control without sugarcane molasses feeding (batch fermentation) was performed during the same period. Biomass production $\left(\mathrm{g} \mathrm{L}^{-1}\right)$, total and reducing sugars $\left(\mathrm{g} \mathrm{L}^{-1}\right)$ and productivity $\left(\mathrm{g} \mathrm{L}^{-1} \mathrm{~h}^{-1}\right)$ were determined for all fermentation essays. Essays were conducted in triplicate. Yield $Y_{\mathrm{x} / \mathrm{s}}(\%)$ and productivity $\left(\mathrm{g} \mathrm{L}^{-1} \mathrm{~h}^{-1}\right)$ were calculated using the following Eq. (1) and (2), respectively:

$$
\begin{aligned}
& Y_{(X / S)}=\left(X_{t}-X_{0}\right) /\left(S_{0}-S_{t}\right)^{*} 100 \\
& \text { Productivity }=X_{t} / t
\end{aligned}
$$

Where: $Y_{(X / S)}=$ biomass yield, \%; $X_{t}=$ biomass at the fermentation time, $g^{-1} ; X_{0}=$ initial biomass, $g^{-1} ; S_{t}=$ total sugars at the fermentation time, $\mathrm{g} \mathrm{L}^{-1} ; \mathrm{S}_{0}=$ initial concentration of total sugars, $\mathrm{g} \mathrm{L}^{-1} ; \mathrm{t}=$ fermentation time, hours.

\section{Selenium accumulation by Saccharomyces boulardii CCT 4308}

Firstly, the tolerance of $S$. boulardii CCT 4308 to sodium selenite $\left(\mathrm{Na}_{2} \mathrm{SeO}_{3}\right)$ that was added to culture medium was analyzed to observe the capacity of cell growth in the presence of Se and accumulation to its microelement. The concentrations of $0,10,50,100,150,200,300$ and $400 \mathrm{mg} \mathrm{mL}^{-1}$ of Se were added in the beginning of $S$. boulardii CCT 4308 cultivation together with inoculation $(10 \% \mathrm{v} / \mathrm{v})$ in $50 \mathrm{~mL}$ of YMB medium. Erlenmeyer flasks were incubated at $30^{\circ} \mathrm{C}$, in a rotatory shaker at $120 \mathrm{rpm}$ for $24 \mathrm{~h}$. Tolerance to Se was evaluated through biomass production analysis and the amount of remaining inorganic Se in the medium.

One-factor-at-a-time experiment was performed to evaluate the effect of Se concentrations $(50,75,100$, 125 , and $150 \mu \mathrm{g} \mathrm{mL}^{-1}$ ) on Se accumulation by S. boulardii CCT 4308. Se was added to the medium at the end of the log phase $(10 \mathrm{~h})$ when yeast growth was at stationary phase and cells would not be so affected by the presence of the microelement. Essays were carried out in $125 \mathrm{~mL}$ Erlenmeyer flasks containing $50 \mathrm{~mL}$ of medium, which were incubated at $30^{\circ} \mathrm{C}$ in a rotatory shaker at $120 \mathrm{rpm}$, for $24 \mathrm{~h}$. Se concentration was determined through biomass production analysis and Se accumulation content. All trials were performed in triplicate. 
Kinetics of biomass production and selenium accumulation by Saccharomyces boulardii CCT 4308 in stirred-tank reactor fed-batch mode

Kinetics of biomass production and Se accumulation by S. boulardii CCT 4308 in fed-batch fermentation in STR were performed using optimized medium and conditions were: $150 \mathrm{~g} \mathrm{~L}^{-1}$ sugarcane molasses, $12 \mathrm{~g} \mathrm{~L}^{-}$ ${ }^{1}$ yeast extract, $10 \%(\mathrm{v} / \mathrm{v})$ of inoculum rate, with feeding of $100 \mathrm{~g} \mathrm{~L}^{-1}$ sugarcane molasses and $100 \mathrm{\mu g} \mathrm{mL}^{-1}$ Se at $4 \mathrm{~h}$ and $10 \mathrm{~h}$, respectively. Experiments were conducted in a 14 L STR (Bioflo ${ }^{\circledR}$ 110; New Brunswick) with a working volume of $9 \mathrm{~L}$. Temperature, $\mathrm{pH}$, aeration, $\mathrm{dO}_{2}$ and agitation were controlled $\left(30^{\circ} \mathrm{C}, \mathrm{pH} 5.5,1\right.$ vvm, 30\% and $300 \mathrm{rpm}$, respectively). Samples were withdrawn each $3 \mathrm{~h}$ during $48 \mathrm{~h}$ with analysis of biomass dry weight $\left(\mathrm{g} \mathrm{L}^{-1}\right)$, total and reducing sugars consumption $\left(\mathrm{g} \mathrm{L}^{-1}\right)$ and Se accumulation ( $\mathrm{mg} \mathrm{g}^{-1}$ of biomass). Essays were conducted in duplicate.

\section{Analytical methods}

The fermented medium was centrifuged at $5,000 \times \mathrm{xg}$ for $15 \mathrm{~min}$ at $4^{\circ} \mathrm{C}$. The supernatant was used for the analysis of residual sugars and residual inorganic Se. Biomass was washed with distilled water and it was re-centrifuged under the same conditions. The supernatant was then discarded and the biomass was dried at $80^{\circ} \mathrm{C}$ until a constant weight using a modified method of Koch [26]. Total sugars determination was performed using the phenol-sulphuric acid method as described by Dubois et al. [27]. Reducing sugars analysis was conducted according to dinitrosalicylic acid (DNS) method as described by Miller [28]. Residual inorganic Se in the medium was analyzed using the modified Azure B reaction [29]. Se accumulation in $S$. boulardii CCT 4308 biomass was determined using flame atomic absorption spectroscopy (FAAS; SPECTRAA 100-200; Varian, USA) at $196 \mathrm{~nm}$ with a spectral slit width of $1 \mathrm{~nm}$. Dried biomass was aciddigested as described by Miekeley et al. [30]. $\mathrm{Na}_{2} \mathrm{SeO}_{3}$ was used as a standard for Se determination.

\section{RESULTS}

\section{Optimization of medium composition for Saccharomyces boulardii CCT 4308 biomass production}

Biomass produced by $S$. boulardii CCT 4308 reached $3.01 \pm 0.16 \mathrm{~g} \mathrm{~L}^{-1}$ at $48 \mathrm{~h}$ of fermentation and a productivity of $0.063 \mathrm{~g} \mathrm{~L}^{-1} \mathrm{~h}^{-1}$ with traditional YMB medium in batch cultivation. The screening of medium components for maximal $S$. boulardii CCT 4308 biomass production was carried out through the use of a $\mathrm{P} \& \mathrm{~B}$ design (Table 2). The effect of eleven compounds (glucose, sugarcane molasses, yeast extract, $\left[\mathrm{NH}_{4}\right]_{2} \mathrm{HPO}_{4}, \mathrm{MgSO}_{4} \cdot 7 \mathrm{H} 2 \mathrm{O}, \mathrm{K}_{2} \mathrm{HPO}_{4}, \mathrm{KH}_{2} \mathrm{PO}_{4}, \mathrm{ZnSO}_{4} \cdot 7 \mathrm{H}_{2} \mathrm{O}, \mathrm{FeSO}_{4} \cdot 7 \mathrm{H}_{2} \mathrm{O}, \mathrm{CuSO}_{4} \cdot 5 \mathrm{H}_{2} \mathrm{O}$, and $\mathrm{MnSO}_{4} \cdot \mathrm{H}_{2} \mathrm{O}$ ) on biomass production showed that sugarcane molasses $(p=0.0001)$ and glucose $(p=0.0094)$ had significant effect according to the analysis of variance (ANOVA; $p<0.05 ; R^{2}=0.92$ ). Other components such as $\left[\mathrm{NH}_{4}\right]_{2} \mathrm{HPO}_{4}, \mathrm{MgSO}_{4} \cdot 7 \mathrm{H}_{2} \mathrm{O}, \mathrm{K}_{2} \mathrm{HPO}_{4}, \mathrm{KH}_{2} \mathrm{PO}_{4}, \mathrm{ZnSO}_{4} \cdot 7 \mathrm{H}_{2} \mathrm{O}, \mathrm{FeSO}_{4} \cdot 7 \mathrm{H}_{2} \mathrm{O}, \mathrm{CuSO}_{4} \cdot 5 \mathrm{H}_{2} \mathrm{O}$, and $\mathrm{MnSO}_{4} \cdot \mathrm{H}_{2} \mathrm{O}$ were not statistically significant $(\mathrm{p}>0.05)$ at tested concentrations. $\mathrm{MgSO}_{4} \cdot 7 \mathrm{H}_{2} \mathrm{O}$ was $\mathrm{p}<0.01$ statistically significant on $S$. boulardii CCT 4308 biomass production but a negative effect at that level tested. Maximal biomass production of $5.42 \mathrm{~g} \mathrm{~L}^{-1}$ was achieved using the following conditions $\left(\mathrm{g} \mathrm{L}^{-1}\right)$ : sugarcane molasses 20.0, yeast extract 15.0, $\left(\mathrm{NH}_{4}\right)_{2} \mathrm{HPO}_{4} 8.0, \mathrm{ZnSO}_{4} 0.01, \mathrm{FeSO} 40.006$ and CuSO4 0.006 (experiment 9). On the other hand, the biomass production dropped to 0.85 and $0.90 \mathrm{~g} \mathrm{~L}^{-1}$ in the absence of sugarcane molasses, glucose and yeast extract (experiment 15 and 16, respectively). These results clearly showed the importance of carbon and nitrogen sources on S. boulardii CCT 4308 biomass production. Although yeast extract was not statistically significant in this study, it was kept to the next steps of optimization to analyze the C:N ratio once yeast extract is an important nutrient for yeast cell growth.

A CCRD was applied to evaluate the optimal concentration of three independent variables (sugarcane molasses, glucose and yeast extract) and the effect of different C:N ratios on S. boulardii CCT 4308 biomass production. According to Table 3, maximal $S$. boulardii CCT 4308 biomass production $\left(9.62 \mathrm{~g} \mathrm{~L}^{-1}\right)$ was reached in the experiment 8: $44 \mathrm{~g} \mathrm{~L}^{-1}$ glucose, $50 \mathrm{~g} \mathrm{~L}^{-1}$ sugarcane molasses and $15 \mathrm{~g} \mathrm{~L}^{-1}$ yeast extract. Lower biomass concentration was obtained $6.08 \mathrm{~g} \mathrm{~L}^{-1}$ with yeast extract concentration of $1.59 \mathrm{~g} \mathrm{~L}^{-1}$ (experiment 13). A higher C:N ratio did not favor S. boulardii CCT 4308 biomass production. The determination coefficient $\left(\mathrm{R}^{2}\right)$ was determined as 0.87 . Yeast extract was statistically significant at $p<0.05$. Sugarcane molasses and glucose did not affect $S$. boulardii CCT 4308 biomass production $(p>0.05)$ in the tested range. Surfaces response graphics (Figure 1) represent the interaction between yeast extract and sugarcane molasses and yeast extract and glucose and the effect on biomass production. A gain of $319.6 \%$ on S. boulardii CCT 4308 biomass production was attained after optimization steps of medium composition. A polynomial model describing the correlation between biomass production (BP) and the three variables $(X=$ glucose, $Y=$ sugarcane molasses, and $Z$ = yeast extract) was determined (Equation 3 ). 
Table 2. P\&B design - Effect of medium components on S. boulardii CCT 4308 biomass production.

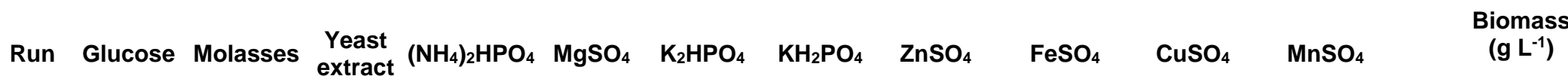

\begin{tabular}{|c|c|c|c|c|c|c|c|c|c|c|c|c|c|}
\hline & & & & & & & & & & & \multirow{2}{*}{$\begin{array}{c}\text { Exp. } \\
4.86\end{array}$} & \multirow{2}{*}{$\begin{array}{c}\text { Pred. } \\
4.63\end{array}$} \\
\hline 1 & $+1(32)$ & $+1(20)$ & $+1(15)$ & $+1(8)$ & $+1(5)$ & $+1(1.0)$ & $+1(1.0)$ & $+1(0.01)$ & $+1(0.006)$ & $+1(0.006)$ & $+1(0.006)$ & & \\
\hline 2 & $+1(32)$ & $+1(20)$ & $+1(15)$ & $-1(0)$ & $+1(5)$ & $+1(1.0)$ & $-1(0)$ & $+1(0.01)$ & $-1(0)$ & $-1(0)$ & $+1(0.006)$ & 4.29 & 4.52 \\
\hline 3 & $+1(32)$ & $+1(20)$ & $-1(0)$ & $+1(8)$ & $+1(5)$ & $-1(0)$ & $+1(1.0)$ & $-1(0)$ & $+1(0.006)$ & $-1(0)$ & $-1(0)$ & 4.39 & 4.43 \\
\hline 4 & $+1(32)$ & $+1(20)$ & $-1(0)$ & $-1(0)$ & $+1(5)$ & $-1(0)$ & $-1(0)$ & $-1(0)$ & $-1(0)$ & $+1(0.006)$ & $-1(0)$ & 3.48 & 4.01 \\
\hline 5 & $+1(32)$ & $-1(0)$ & $+1(15)$ & $+1(8)$ & $-1(0)$ & $+1(1.0)$ & $+1(1.0)$ & $-1(0)$ & $-1(0)$ & $+1(0.006)$ & $-1(0)$ & 2.79 & 3.42 \\
\hline 6 & $+1(32)$ & $-1(0)$ & $+1(15)$ & $-1(0)$ & $-1(0)$ & $+1(1.0)$ & $1(0)$ & $-1(0)$ & $+1(0.006)$ & $-1(0)$ & $-1(0)$ & 3.49 & 3.42 \\
\hline 7 & $+1(32)$ & $-1(0)$ & $-1(0)$ & $1(8)$ & $-1(0)$ & $-1(0)$ & $+1(1.0)$ & $+1(0.01)$ & $-1(0)$ & $-1(0)$ & $+1(0.006)$ & 2.83 & 3.16 \\
\hline 8 & $+1(32)$ & $-1(0)$ & $-1(0)$ & $-1(0)$ & $-1(0)$ & $-1(0)$ & $-1(0)$ & $+1(0.01)$ & $+1(0.006)$ & $+1(0.006)$ & $+1(0.006)$ & 2.89 & 2.56 \\
\hline 9 & $-1(0)$ & $+1(20)$ & $+1(15)$ & $+1(8)$ & $-1(0)$ & $-1(0)$ & $-1(0)$ & $+1(0.01)$ & $+1(0.006)$ & $+1(0.006)$ & $-1(0)$ & 5.42 & 5.09 \\
\hline 10 & $-1(0)$ & $+1(20)$ & $+1(15)$ & $-1(0)$ & $-1(0)$ & $-1(0)$ & $+1(1.0)$ & $+1(0.01)$ & $-1(0)$ & $-1(0)$ & $-1(0)$ & 3.86 & 4.20 \\
\hline 11 & $-1(0)$ & $+1(20)$ & $-1(0)$ & $+1(8)$ & $-1(0)$ & $+1(1.0)$ & $-1(0)$ & $-1(0)$ & $+1(0.006)$ & $-1(0)$ & $+1(0.006)$ & 3.82 & 3.75 \\
\hline 12 & $-1(0)$ & $+1(20)$ & $-1(0)$ & $-1(0)$ & $-1(0)$ & $+1(1.0)$ & $+1(1.0)$ & $-1(0)$ & $-1(0)$ & $+1(0.006)$ & $+1(0.006)$ & 3.40 & 4.04 \\
\hline 13 & $-1(0)$ & $-1(0)$ & $+1(15)$ & $+1(8)$ & $+1(5)$ & $-1(0)$ & $-1(0)$ & $-1(0)$ & $-1(0)$ & $+1(0.006)$ & $+1(0.006)$ & 0.96 & 1.48 \\
\hline 14 & $-1(0)$ & $-1(0)$ & $+1(15)$ & $-1(0)$ & $+1(5)$ & $-1(0)$ & $+1(1.0)$ & $-1(0)$ & $+1(0.006)$ & $-1(0)$ & $+1(0.006)$ & 1.31 & 1.35 \\
\hline 15 & $-1(0)$ & $-1(0)$ & $-1(0)$ & $+1(8)$ & $+1(5)$ & $+1(1.0)$ & $-1(0)$ & $+1(0.01)$ & $-1(0)$ & $-1(0)$ & $-1(0)$ & 0.85 & 1.07 \\
\hline 16 & $-1(0)$ & $-1(0)$ & $-1(0)$ & $-1(0)$ & $+1(5)$ & $+1(1.0)$ & $+1(1.0)$ & $+1(0.01)$ & $+1(0.006)$ & $+1(0.006)$ & $-1(0)$ & 0.90 & 0.67 \\
\hline 17 & $0(16)$ & $0(10)$ & $0(7.5)$ & $0(4)$ & $0(2.5)$ & $0(0.5)$ & $0(0.5)$ & $0(0.005)$ & $0(0.003)$ & $0(0.003)$ & $0(0.003)$ & 3.92 & 3.24 \\
\hline 18 & $0(16)$ & $0(10)$ & $0(7.5)$ & $0(4)$ & $0(2.5)$ & $0(0.5)$ & $0(0.5)$ & $0(0.005)$ & $0(0.003)$ & $0(0.003)$ & $0(0.003)$ & 4.06 & 3.24 \\
\hline 19 & $0(16)$ & $0(10)$ & $0(7.5)$ & $0(4)$ & $0(2.5)$ & $0(0.5)$ & $0(0.5)$ & $0(0.005)$ & $0(0.003)$ & $0(0.003)$ & $0(0.003)$ & 4.01 & 3.24 \\
\hline
\end{tabular}

$\mathrm{BP}=8.66-0.15 X-0.022 \mathrm{X}^{2}+0.43 \mathrm{Y}+0.04 \mathrm{Y}^{2}+1.24 Z-0.85 Z^{2}+0.47 \mathrm{XY}+0.25 X Z+0.26 \mathrm{Y}$ 
Optimized conditions (glucose $44 \mathrm{~g} \mathrm{~L}^{-1}$, sugarcane molasses $50 \mathrm{~g} \mathrm{~L}^{-1}$ and yeast extract $15 \mathrm{~g} \mathrm{~L}^{-1}$ ) were then employed in validation experiments of biomass production $\left(9.22 \pm 0.11 \mathrm{~g} \mathrm{~L}^{-1}\right)$.
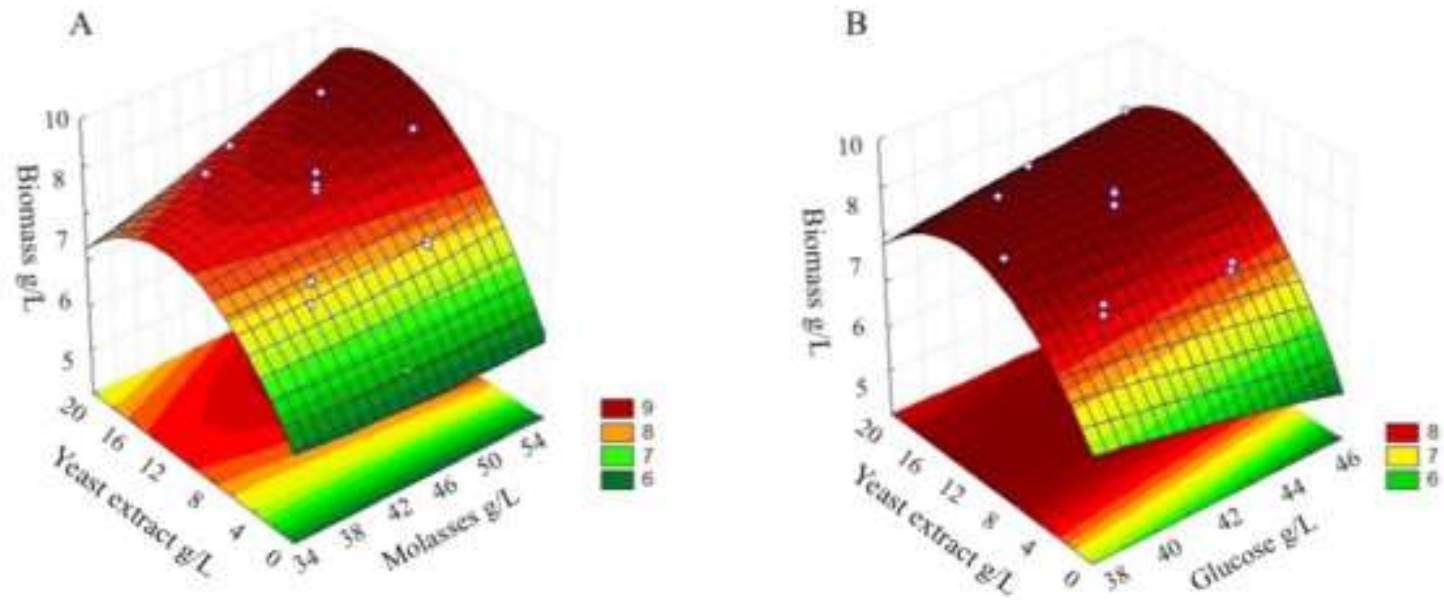

Figure 1. Surface response graphs representing the effect of factors' interaction on $S$. boulardii CCT 4308 biomass production a) yeast extract and molasses and b) yeast extract and glucose.

Table 3. $2^{3}$ CCRD design - Evaluation of medium components for S. boulardii CCT 4308 biomass production.

\begin{tabular}{cccccc}
\hline \multirow{2}{*}{ Run } & \multicolumn{3}{c}{ Variables $\left(\mathbf{g ~ L}^{-1}\right)$} & \multicolumn{2}{c}{ Biomass $\left.\mathbf{g ~ L ~}^{-1}\right)$} \\
\cline { 2 - 6 } & Glucose & Molasses & Yeast extract & Experimental & Predicted \\
\hline 1 & $-1(40)$ & $-1(40)$ & $-1(5)$ & 8.08 & 7.98 \\
2 & $-1(40)$ & $-1(40)$ & $+1(15)$ & 8.92 & 8.70 \\
3 & $-1(40)$ & $+1(50)$ & $-1(5)$ & 7.85 & 7.68 \\
4 & $-1(40)$ & $+1(50)$ & $+1(15)$ & 8.66 & 8.92 \\
5 & $+1(44)$ & $-1(40)$ & $-1(5)$ & 7.59 & 7.11 \\
6 & $+1(44)$ & $-1(40)$ & $+1(15)$ & 8.39 & 8.34 \\
7 & $+1(44)$ & $+1(50)$ & $-1(5)$ & 7.75 & 7.74 \\
8 & $+1(44)$ & $+1(50)$ & $+1(15)$ & 9.62 & 9.50 \\
9 & $-1.68(38.64)$ & $0(45)$ & $0(10)$ & 8.72 & 8.75 \\
10 & $+1.68(45.36)$ & $0(45)$ & $0(10)$ & 8.22 & 8.50 \\
11 & $0(42)$ & $-1.68(36.59)$ & $0(10)$ & 7.96 & 8.36 \\
12 & $0(42)$ & $+1.68(53.41)$ & $0(10)$ & 9.16 & 9.08 \\
13 & $0(42)$ & $0(45)$ & $-1.68(1.59)$ & 6.08 & 6.42 \\
14 & $0(42)$ & $0(45)$ & $+1.68(18.41)$ & 8.53 & 8.50 \\
15 & $0(42)$ & $0(45)$ & $0(10)$ & 9.11 & 8.66 \\
16 & $0(42)$ & $0(45)$ & $0(10)$ & 8.84 & 8.66 \\
17 & $0(42)$ & $0(45)$ & $0(10)$ & 8.09 & 8.66 \\
\hline
\end{tabular}

\section{Effect of sugarcane molasses as sole carbon source on Saccharomyces boulardii CCT 4308 biomass production}

Different concentrations of sugarcane molasses were used as sole carbon source. The best result was obtained with $150 \mathrm{~g} \mathrm{~L}^{-1}$ of sugarcane molasses with $\mathrm{Y}_{\mathrm{x} / \mathrm{s}}$ of $17 \%$ and biomass production of $9.89 \pm 0.24 \mathrm{~g} \mathrm{~L}^{-1}$. A higher concentration of sugarcane molasses $\left(200 \mathrm{~g} \mathrm{~L}^{-1}\right)$ promoted a higher biomass production of $10.75 \pm$ $0.61 \mathrm{~g} \mathrm{~L}^{-1}$ but a lower $Y_{\mathrm{x} / \mathrm{s}}$ of $15 \%$. According to Tukey's test, $150 \mathrm{~g} \mathrm{~L}^{-1}$ and $200 \mathrm{~g} \mathrm{~L}^{-1}$ of molasses did not show 
statistical difference on biomass production. For this reason, the concentration of $150 \mathrm{~g} \mathrm{~L}^{-1}$ molasses was chosen for further experiments. Also, these values demonstrated that sugarcane molasses possessed great potential to replace glucose in the medium for probiotic biomass S. boulardii CCT 4308 cultivation with lower costs.

\section{Batch and fed-batch fermentation for Saccharomyces boulardii CCT 4308 biomass production}

Kinetics of $S$. boulardii CCT 4308 biomass production and sugar consumption were performed in batch and fed-batch fermentation, in Erlenmeyer flasks and STR. In batch and fed-batch mode, the inoculum was then cultivated in the optimized medium, which facilitated its adaptation. S. boulardii CCT 4308 reached the stationary phase after $16 \mathrm{~h}$ of batch fermentation in Erlenmeyer flasks (Figure 2).

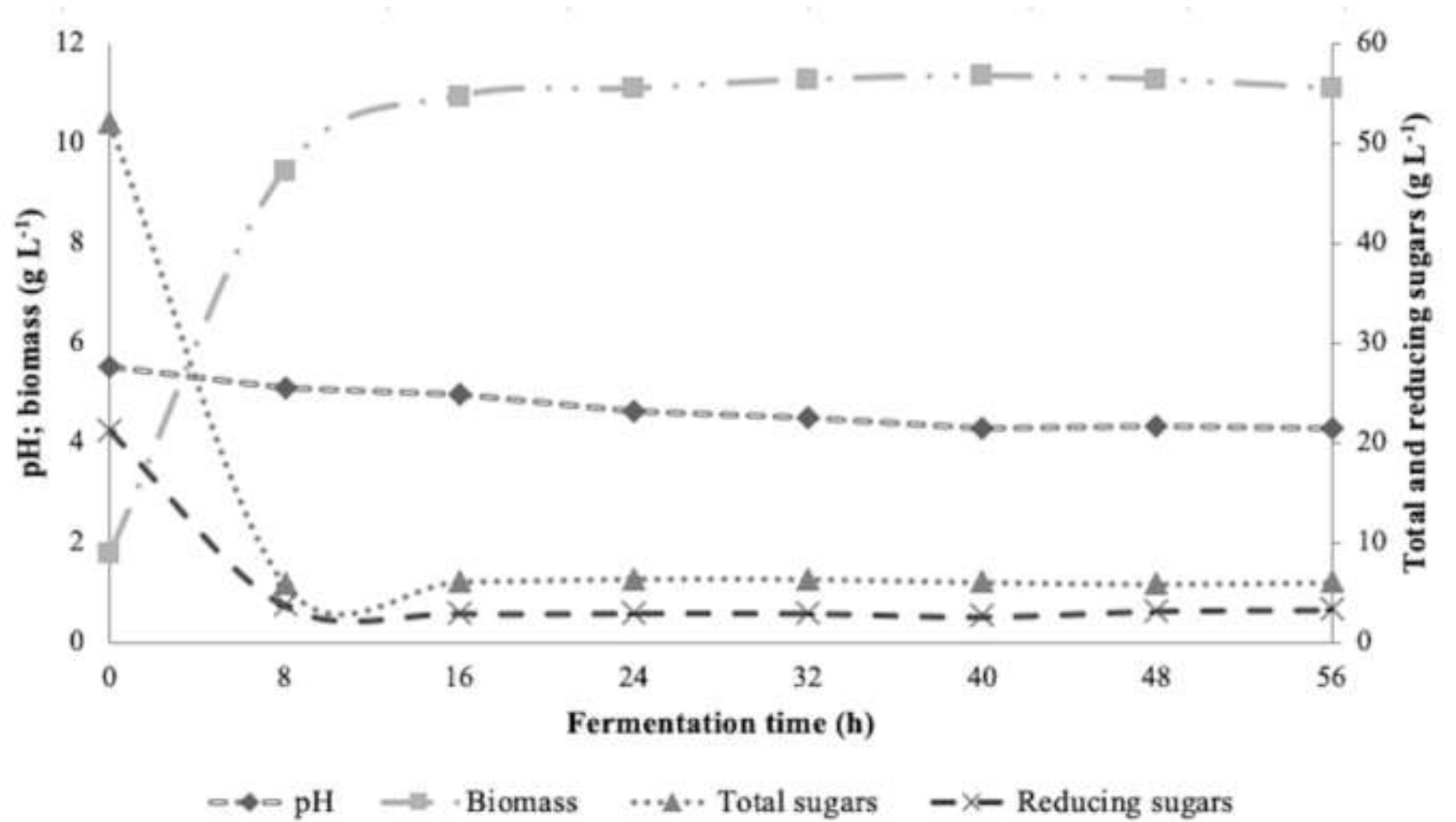

Figure 2. Kinetics of $S$. boulardii CCT 4308 biomass production in Erlenmeyer flasks in batch mode under optimized medium conditions (biomass, $\mathrm{pH}$, total sugars and reducing sugars).

Biomass production attained $11.10 \pm 0.19 \mathrm{~g} \mathrm{~L}^{-1}$ at $24 \mathrm{~h}$, with a productivity of $0.46 \mathrm{~g} \mathrm{~L}^{-1} \mathrm{~h}^{-1}$ and almost completed consumption of total and reducing sugars after $8 \mathrm{~h}$ of process, reaching a final concentration of 6.0 and $3.0 \mathrm{~g} \mathrm{~L}^{-1}$, respectively, in Erlenmeyer flasks. The $\mathrm{pH}$ values presented a slight variation from 5.5 to 4.7. In STR, biomass reached $11.37 \mathrm{~g} \mathrm{~L}^{-1}$ at $12 \mathrm{~h}$ of fermentation and a higher productivity of $0.95 \mathrm{~g} \mathrm{~L}^{-1} \mathrm{~h}^{-1}$, with total sugars consumption of $50 \%$ after $8 \mathrm{~h}$ of fermentation (Figure 3 ). Then, the fermentation time in STR was reduced to $12 \mathrm{~h}$ compared to $24 \mathrm{~h}$ required in Erlenmeyer flask batch studies. 


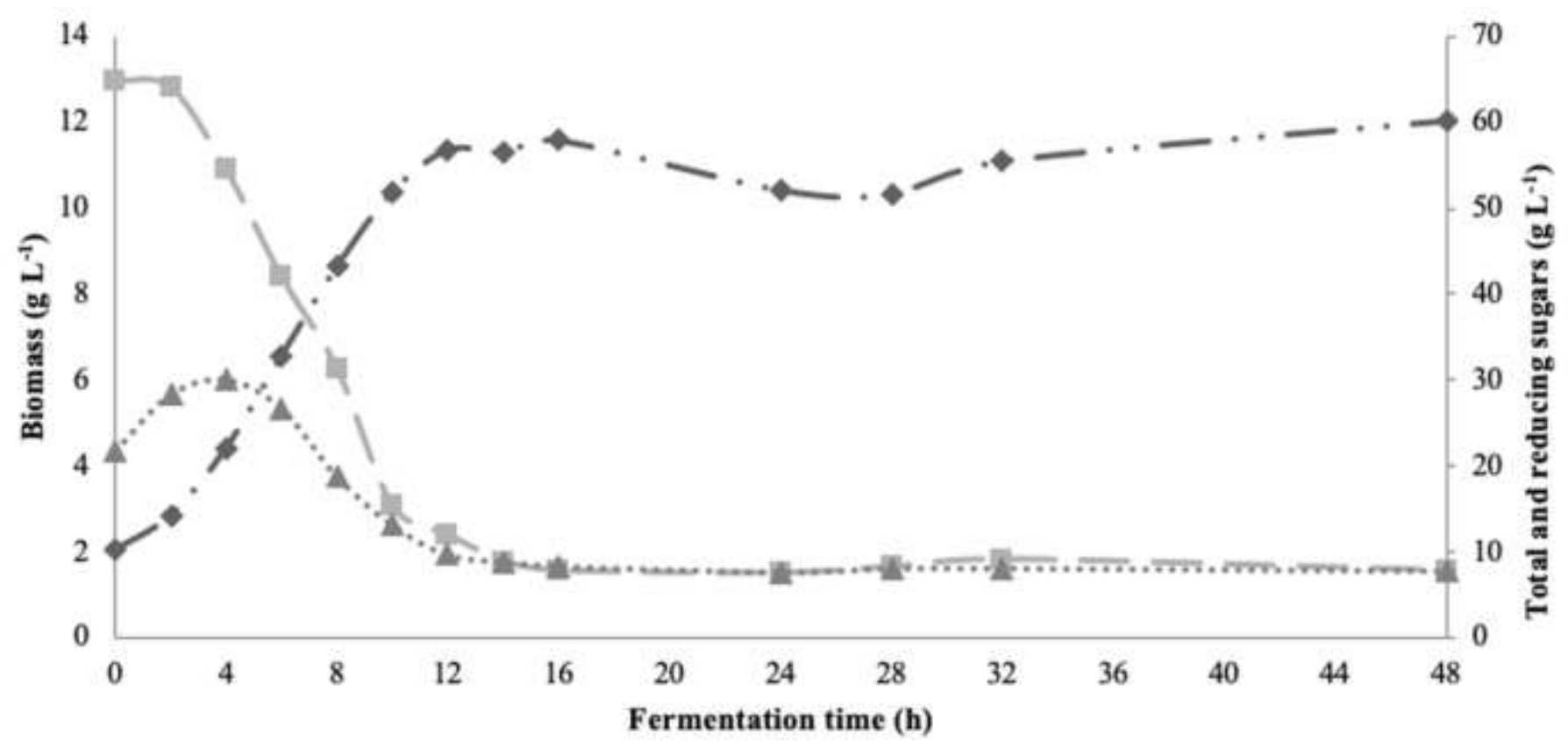

$\rightarrow$ Biomass $\quad \rightarrow \cdot$ Total sugars $\quad \cdots \cdots \cdot$ Reducing sugars

Figure 3. Kinetics of $S$. boulardii CCT 4308 biomass production in STR in batch mode under optimized medium conditions (biomass, total and reducing sugars).

Molasses feeding was tested in a fed-batch mode. The control (no sugarcane molasses feeding) in Erlenmeyer flasks led to a $S$. boulardii CCT 4308 biomass production of $10.74 \pm 0.40 \mathrm{~g} \mathrm{~L}^{-1}$ at $10 \mathrm{~h}$ of cultivation, while fed-batch process in Erlenmeyer flasks promoted $13.18 \pm 0.19 \mathrm{~g} \mathrm{~L}^{-1}$ and $13.11 \pm 0.45 \mathrm{~g} \mathrm{~L}^{-1}$ of biomass production with feeding at 4 and $6 \mathrm{~h}$, respectively. The $\mathrm{pH}$ showed a slight variation from 5.5 to 5.1 . Sugarcane molasses feeding notably increased (22.7\%) biomass production when compared to batch process (no sugarcane molasses feeding). Reducing sugars concentration $3.80 \pm 0.11 \mathrm{~g} \mathrm{~L}^{-1}$ in the end of batch process, and $6.81 \pm 0.19 \mathrm{~g} \mathrm{~L}^{-1}$ in fed-batch process. Biomass $\left(\mathrm{g} \mathrm{L}^{-1}\right)$, yield (\%), productivity $\left(\mathrm{g} \mathrm{L}^{-1} \mathrm{~h}^{-1}\right)$, total sugars $\left(\mathrm{g} \mathrm{L}^{-1}\right)$ and reducing sugars $\left(\mathrm{g} \mathrm{L}^{-1}\right)$ were determined for fed-batch processes in Erlenmeyer flasks, which are shown in Table 4.

Table 4. S. boulardii CCT 4308 biomass, yield and productivity in fed-batch process with molasses feeding in Erlenmeyer flasks.

\begin{tabular}{lccccc}
\hline \multicolumn{1}{c}{ Condition } & Biomass $\left(\mathbf{g ~ L}^{-1}\right)$ & Yield $\mathbf{Y}_{\mathbf{x} / \mathbf{s}}(\%)$ & $\begin{array}{c}\text { Productivity } \\
\left(\mathbf{g ~ L}^{-1} \mathbf{h}^{-1}\right)\end{array}$ & $\begin{array}{c}\text { Total sugars } \\
\left(\mathbf{g ~ L}^{-1}\right)\end{array}$ & $\begin{array}{c}\text { Reducing } \\
\text { sugars }\left(\mathbf{g ~ L}^{-1}\right)\end{array}$ \\
\hline No feeding & $10.74^{\mathrm{a}} \pm 0.40$ & 17.08 & 1.07 & $7.14 \pm 0.18$ & $3.80 \pm 0.11$ \\
Molasses feeding at 4 $\mathrm{h}$ & $13.18^{\mathrm{b}, \mathrm{c}} \pm 0.19$ & 23.16 & 1.32 & $11.42 \pm 1.48$ & $6.81 \pm 0.19$ \\
Molasses feeding at 6 $\mathrm{h}$ & $13.11^{\mathrm{c}} \pm 0.45$ & 22.32 & 1.31 & $9.77 \pm 0.07$ & $6.21 \pm 0.08$ \\
\hline
\end{tabular}

Tukey multiple comparisons test $(\mathrm{p}<0.05)$, same letters codes do not differ significantly and different letters indicate significant differences.

As it could be seen, molasses feeding after $4 \mathrm{~h}$ or $6 \mathrm{~h}$ did not showed a statistically significant $(\mathrm{p}>0.05)$ influence on S. boulardii CCT 4308 biomass production according to Tukey's test. However, the results obtained with molasses feeding after $4 \mathrm{~h}$ was slightly better with a yield of $23.16 \%$ compared to $22.32 \%$ of 6 $\mathrm{h}$ feeding, 22.7\% higher biomass production than control (batch fermentation) and better productivity of 1.32 $\mathrm{g} \mathrm{L}^{-1} \mathrm{~h}^{-1}$ as well. In this way, molasses feeding at $4 \mathrm{~h}$ condition was selected for the next study of biomass production with selenium accumulation. After optimization, S. boulardii CCT 4308 biomass production (13.18 $\left.\pm 0.19 \mathrm{~g} \mathrm{~L}^{-1}\right)$ was 4.38 -fold higher and a 20.95 -fold higher productivity $\left(1.32 \mathrm{~g} \mathrm{~L}^{-1} \mathrm{~h}^{-1}\right)$ compared to initial conditions. 


\section{Selenium accumulation by Saccharomyces boulardii CCT 4308}

S. boulardii CCT 4308 tolerance to different Se concentrations (from 0 to $400 \mu \mathrm{g} \mathrm{mL}^{-1}$ ) was investigated (Table 5). Biomass production reached a maximum of $1.41 \mathrm{~g} \mathrm{~L}^{-1}$ and $65 \%$ of Se accumulation with addition of $10 \mu \mathrm{g} \mathrm{mL}-1$ of Se to the medium. At $50 \mu \mathrm{g} \mathrm{mL}^{-1}$ of Se, biomass production reached only $0.96 \mathrm{~g} \mathrm{~L}^{-1}$, which represented $24.56 \%$ of Se accumulation. Over $150 \mu \mathrm{g} \mathrm{mL}^{-1}$ of Se, biomass production was around 0.30-0.35 $\mathrm{g} \mathrm{L}^{-1}$ and very low Se accumulation. Thus, the tested Se concentrations tended to inhibit yeast growth, probably due to Se toxicity to $S$. boulardii CCT 4308 cells.

Table 5. S. boulardii strain CCT 4308 tolerance to different Se concentrations.

\begin{tabular}{ccc}
\hline Se $\left(\mu \mathbf{g ~ m L}^{-1}\right)$ & Biomass $\left(\mathbf{g ~ L}^{-1}\right)$ & Remaining Se $\left(\boldsymbol{\mu g ~ \mathbf { ~ m L } ^ { - 1 } )}\right.$ (supernatant) \\
\hline 0 & $2.69^{\mathrm{a}} \pm 2.76 \mathrm{E}-03$ & $0 \pm 0.04$ \\
10 & $1.41^{\mathrm{b}} \pm 8.49 \mathrm{E}-04$ & $3.52 \pm 0.87$ \\
50 & $0.96^{\mathrm{c}} \pm 7.07 \mathrm{E}-04$ & $37.72 \pm 1.58$ \\
100 & $0.49^{\mathrm{d}} \pm 4.81 \mathrm{E}-03$ & $100.38 \pm 1.36$ \\
150 & $0.32^{\mathrm{e}} \pm 1.48 \mathrm{E}-03$ & $141.03 \pm 1.78$ \\
200 & $0.30^{\dagger} \pm 7.07 \mathrm{E}-05$ & $199.14 \pm 1.95$ \\
300 & $0.35^{\mathrm{g}} \pm 7.07 \mathrm{E}-05$ & $219.65 \pm 1,27$ \\
400 & $0.36^{\mathrm{g}} \mathrm{h} \pm 7.07 \mathrm{E}-05$ & $380.41 \pm 1.02$ \\
\hline
\end{tabular}

Tukey multiple comparisons test $(p<0.05)$, same letters codes do not differ significantly and different letters indicate significant differences.

In this way, different Se concentrations $\left(50,75,100,125\right.$, and $\left.150 \mu \mathrm{gL} \mathrm{m}^{-1}\right)$ were added in the medium after $10 \mathrm{~h}$ of fermentation, end of logarithmic phase, to evaluate S. boulardii CCT 4308 growth. Biomass production and Se accumulation ( $\mathrm{mg} \mathrm{g}^{-1} \mathrm{Se}$ in biomass) were determined after $48 \mathrm{~h}$ of cultivation. The results are shown in Table 6. The best biomass production (13.31 $\pm 0.17 \mathrm{~g} \mathrm{~L}^{-1}$ ) was reached with $50 \mu \mathrm{gL} \mathrm{m}^{-1} \mathrm{Se}$ concentration. However, the best Se accumulation condition was observed with the addition of $100 \mu \mathrm{gL}^{-1}$, where accumulation yield was $37.89 \%$. According to Tukey's test, $50 \mu \mathrm{g} \mathrm{mL}^{-1}$ Se and $100 \mu \mathrm{g} \mathrm{mL}^{-1}$ did not show statistical difference $(p<0.05)$.

Table 6. Se accumulation by S. boulardii CCT 4308 at different Se concentrations added in the medium.

\begin{tabular}{|c|c|c|c|c|}
\hline $\begin{array}{c}\mathrm{Se} \\
\left(\mu \mathrm{g} \mathrm{mL}^{-1}\right)\end{array}$ & $\begin{array}{c}\text { Biomass } \\
\left(g^{-1}\right)\end{array}$ & $\begin{array}{c}\text { Biomass } \\
\text { decrease } \\
(\%)\end{array}$ & $\begin{array}{c}\text { Absorbed Se } \\
(\%)\end{array}$ & $\begin{array}{l}\text { Se accumulation } \\
\text { (mg Se } \mathrm{g}^{-1} \text { biomass) }\end{array}$ \\
\hline 50 & $13.31^{a} \pm 0.17$ & 3.38 & 25.62 & $1.54^{a} \pm 0.25$ \\
\hline 75 & $13.18^{a} \pm 0.13$ & 4.34 & 34.05 & $3.08^{a} \pm 0.07$ \\
\hline 100 & $12.66^{a, b} \pm 0.20$ & 4.79 & 37.89 & $4.56^{\mathrm{a}} \pm 0.44$ \\
\hline 125 & $12.37^{b} \pm 0.05$ & 6.93 & 31.39 & $4.73^{a} \pm 0.66$ \\
\hline 150 & $12.12^{b, c} \pm 0.08$ & 8.84 & 24.78 & $4.48^{a} \pm 0.99$ \\
\hline
\end{tabular}

Tukey multiple comparisons test $(\mathrm{p}<0.05)$, same letters codes do not differ significantly and different letters indicate significant differences.

Therefore, as a strategy to avoid Se toxic effects the addition of Se was at the end of logarithmic phase, as corroborated by Ponce de Léon et al. [19] and Wang et al. [25]. These results showed that S. boulardii CCT 4308 had an efficient mechanism that enable to absorb Se. Se-enriched probiotic S. boulardii CCT 4308 biomass production was carried out in 14-L STR bioreactor with optimized conditions (150 $\mathrm{g} \mathrm{L}^{-1}$ sugarcane molasses and $12 \mathrm{~g} \mathrm{~L}^{-1}$ yeast extract) and $100 \mathrm{~g} \mathrm{~L}^{-1}$ molasses feeding after $4 \mathrm{~h}$ and $100 \mathrm{gg} \mathrm{mL}^{-1}$ of Se after 10 $\mathrm{h}$ of fermentation (Figure 4). Best biomass production reached $14.52 \mathrm{~g} \mathrm{~L}^{-1}$ at $12 \mathrm{~h}$, with a productivity of 1.21 $\mathrm{g} \mathrm{L}^{-1} \mathrm{~h}^{-1}$ and $3.20 \mathrm{mg}$ Se accumulation $\mathrm{g}^{-1}$ biomass. 


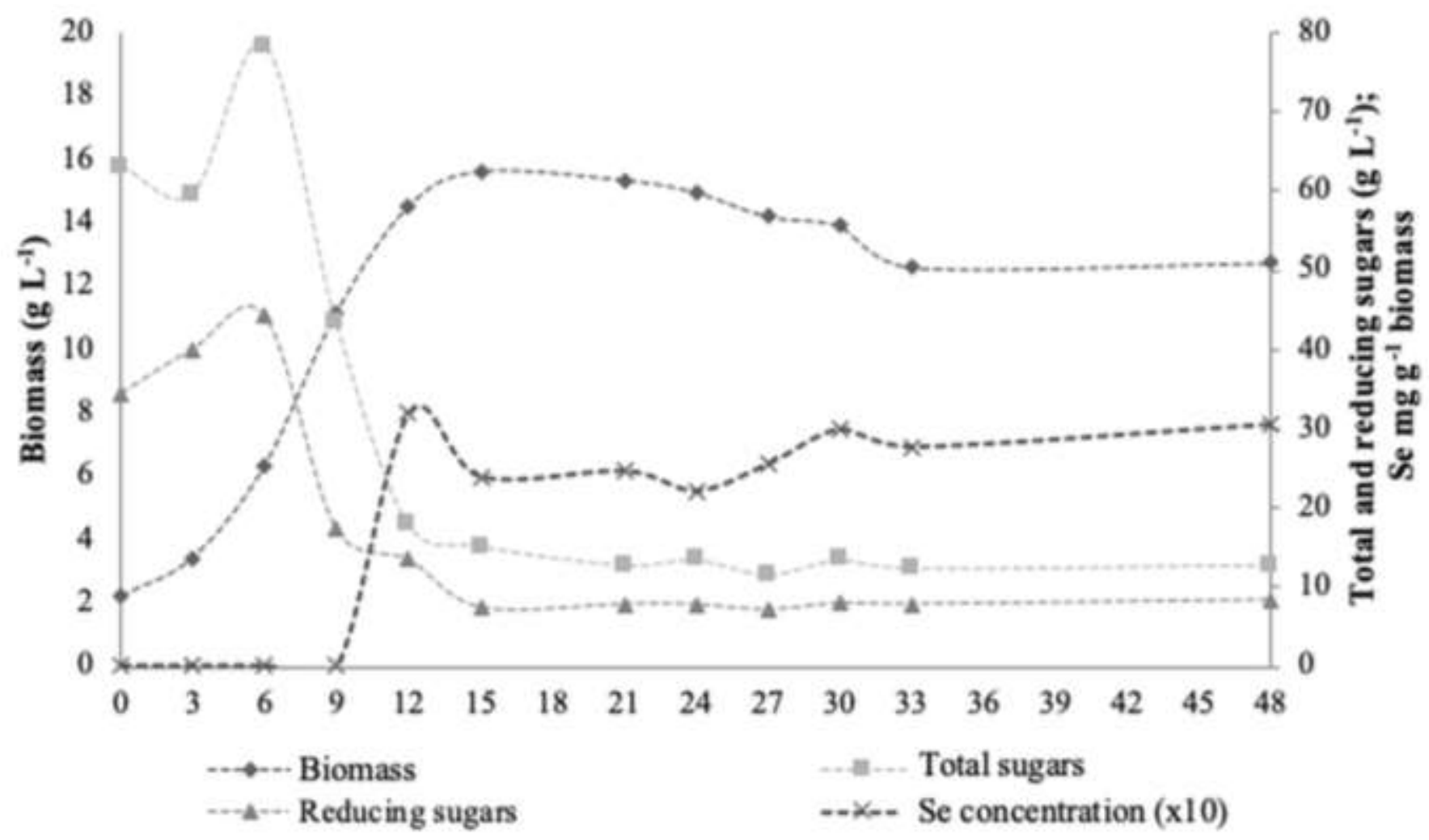

Figure 4. Kinetics of $S$. boulardii CCT 4308 cultivation for biomass production and Se accumulation in STR in fed-batch mode under optimized conditions (biomass, Se accumulation, total sugars and reducing sugars).

\section{DISCUSSION}

Sugarcane molasses is a by-product of the sugarcane industry [23]. Due to its abundant availability and composition, it can use as substrate for microbial processes to produce value-added products. S. cerevisiae and $S$. boulardii biomass production in molasses medium have been already reported in literature $[30,22,5]$. However, it is the first time that Se-enriched $S$. boulardii biomass produced was conducted using sugarcane molasses in fed-batch fermentation. The most reported studies in the literature were related to Se-enriched $S$. cerevisiae biomass, while few works were related to $S$. boulardii and its probiotic properties $[31,32]$. The first screening employing a P\&B design showed that sugarcane molasses and glucose influenced biomass production. It is known that molasses is a complex carbon source that is composed of sucrose, glucose, fructose, small amounts of proteins, vitamins, polysaccharides and nitrogen compounds. Sindhu et al. [23] reported that it was also composed by several minerals, such as $\mathrm{K}^{+}, \mathrm{Fe}^{2+}, \mathrm{Ca}^{2+}, \mathrm{Mg}^{2+}, \mathrm{Na}^{+}, \mathrm{Mn}^{2+}, \mathrm{Zn}^{2+}, \mathrm{Cu}^{2+}$ and $\mathrm{F}^{-}$. Thus, with $50 \%$ content of fermentable sugars, sugarcane molasses was considered a good feedstock for fermentation processes when compared to other carbon sources. The results of CCRD indicated that sugarcane molasses and glucose in the medium were not sufficient for an optimal yeast biomass production. Furthermore, Figure 1A indicated that higher concentrations of molasses could lead to an optimum region of yeast cell growth, so further analysis were performed to evaluate this hypothesis. Some studies reported optimization as a tool to improve yeast biomass production. Trigueros et al. [33] presented an optimum biomass value of $8.20 \mathrm{~g} \mathrm{~L}^{-1}$ by Saccharomyces cerevisiae var. boulardii under batch operation using $40 \mathrm{~g} \mathrm{~L}^{-}$ ${ }^{1}$ hydrolyzed cheese whey agro-residue. In the optimization of molasses medium, $S$. cerevisiae produced $6.69 \mathrm{~g} \mathrm{~L}^{-1}$ of biomass [22]. Biomass production by $S$. cerevisiae increased from $3.73 \mathrm{~g} \mathrm{~L}^{-1}$ to $5.89 \mathrm{~g} \mathrm{~L}^{-1}$ by statistical tools [34].

Previous fed-batch cultivation studies in bioreactors had successful Se accumulation, but there were only reports by $S$. cerevisiae. A fed-batch process with a high $S$. cerevisiae biomass production of $37 \mathrm{~g} \mathrm{~L}^{-1}$ was developed by Demirci and Pometto III [14] with $2.84 \mathrm{mg} \mathrm{Se}^{-1}$ dry biomass with a single-dose addition of Se. The same authors proposed a continuous addition of Se where biomass reached $45 \mathrm{~g} \mathrm{~L}^{-1}$ and $2.49 \mathrm{mg}$ $\mathrm{g}^{-1}$ Se dry biomass. Rajashree and Muthukumar [31] yielded $32.09 \mathrm{~g} \mathrm{~L}^{-1}$ of dry S. cerevisiae cell biomass in fed-batch fermentation in $10 \mathrm{~L}$ bioreactor with a working volume of $7 \mathrm{~L}$ containing $3.75 \mathrm{mg} \mathrm{g}^{-1}$ of Se. This is the first report involving Saccharomyces boulardii CCT 4308 Se-enriched biomass cultivation in fed-batch mode. 
Toxic effects of some elements on yeasts growth have been described in literature. This behavior was first noticed by Tuite and Oliver [35], who showed that $\mathrm{Se}, \mathrm{Ag}, \mathrm{As}$, and $\mathrm{Pb}$ can negatively affect yeast growth at concentrations higher than $100 \mu \mathrm{mol} \mathrm{L}^{-1}\left(7.9 \mu \mathrm{g} \mathrm{mL}^{-1}\right.$ in the case of Se), which may affect cells division. For that reason, it is widely common that different fungi species exhibited a specific concentration in absorbing mineral components [13]. According to some authors Volesky and May-Phillips [36] and Kieliszek [37] first the microelement rapid binds on the cell wall surface. Then, Se is subsequently adsorbed on anionic binding sites of the cell structure. However, the rate of metal accumulation depends on microbial metabolism. Hence, the Se accumulation profile that is shown in Figure 4 corroborated with Volesky and May-Phillips [36] and Kieliszek [37], once highest Se accumulation of $3.20 \mathrm{mg} \mathrm{g}^{-1}$ was observed at $12 \mathrm{~h}$ of fermentation, which meant a rapid binding of the microelement on the cell surface and then, from 15 to $48 \mathrm{~h}$, the Se accumulation into yeast cells was established.

Some data about Se accumulation can be found in literature, but only by $S$. cerevisiae. Suhajda et al. [38] reported that $30 \mu \mathrm{g} \mathrm{mL}^{-1}$ Se were added during the exponential growth phase in the culture medium, which resulted in Se accumulation in the range of $1200-1400 \mathrm{\mu g} \mathrm{g}^{-1}$ dried biomass yeast. Natural medium for Se-enriched yeast ( $S$. cerevisiae) production was investigated by Yin et al. [7]. The medium was composed of juices from germinated brown rice (12 ${ }^{\circ}$ Brix), beerwort ( $\left.12^{\circ} \mathrm{Brix}\right)$ and soybean sprout ( $\left.12^{\circ} \mathrm{Brix}\right)$, with addition of $15 \mu \mathrm{g} \mathrm{mL}^{-1}$ of $\mathrm{Na}_{2} \mathrm{SeO}_{3}$. The results showed that the components mixed ratio of 4:4:2 (v:v:v) obtained the maximum value of biomass and total Se yield were $8.5 \mathrm{~g} \mathrm{~L}^{-1}$ and $3.53 \mathrm{mg} \mathrm{L}^{-1}$, respectively. Rajashree and Muthukumar [39] reported the Se accumulation of $2.72 \mathrm{mg} \mathrm{g}^{-1}$ and $2.46 \mathrm{mg} \mathrm{g}^{-1}$ by S. cerevisiae in a synthetic medium and industrial medium, respectively, yielding a maximum yeast biomass of $12.8 \mathrm{~g} \mathrm{~L}^{-1}$ and $10.2 \mathrm{~g} \mathrm{~L}^{-1}$, respectively. Alidee et al. [22] achieved $3.77 \mathrm{mg} \mathrm{g}^{-1}$ of Se and $6.69 \mathrm{~g} \mathrm{~L}^{-1}$ of biomass by $S$. cerevisiae in a medium of beet and sugarcane molasses (ratio of 1:1) as carbon sources.

The accumulated Se by $S$. boulardii CCT 4308 biomass is comparable to some commercial products available on the market, which contain about $2.5 \mathrm{mg} \mathrm{Se} \mathrm{g}^{-1}$ dry biomass [40]. This fact showed great advantageous perspective of the developed process. Saccharomyces boulardii is recognized as an important probiotic microorganism. Few works comprising its biomass production have been published so far, mainly concerning Se accumulation. Very good perspectives were then achieved for this work. A simple and costeffective bioprocess was developed to produce Se-enriched probiotic biomass by S. boulardii CCT 4308. The results obtained in these studies will certainly be useful in further bioprocess development of valuable products for human and animal health. The process can also be scaled-up, which may certainly interest for the pharmaceutical industry.

\section{CONCLUSION}

A new bioprocess was developed for $S$. boulardii CCT 4308 Se-enriched biomass production using sugarcane molasses agro-industrial residue in fed-batch fermentation at bench scale. Optimization of medium composition led to a 4.82-fold improvement of biomass production compared to initial conditions. Optimized medium was composed of $150 \mathrm{~g} \mathrm{~L}^{-1}$ sugarcane molasses and $12 \mathrm{~g} \mathrm{~L}^{-1}$ yeast extract. Even though yeasts accumulate some minerals in a natural pathway, these findings proved the potential of the strain $S$. boulardii CCT 4308 cells to tolerate and accumulate Se. The most effective fed-batch culture was attained with feeding of $100 \mathrm{~g} \mathrm{~L}^{-1}$ sugarcane molasses and $100 \mu \mathrm{g} \mathrm{mL}^{-1}$ of Se at $4 \mathrm{~h}$ and $10 \mathrm{~h}$ of fermentation, respectively. Accordingly, Se-enriched S. boulardii CCT 4308 biomass production reached $14.52 \mathrm{~g} \mathrm{~L}^{-1}$ with Se accumulation of $3.20 \mathrm{mg} \mathrm{Se} \mathrm{g}^{-1}$ biomass at $12 \mathrm{~h}$, which was comparable with available commercial products. A simple and low-cost bioprocess was developed for a probiotic Se-enriched yeast biomass production with great application perspectives for human and animal health as well.

Funding: Authors want to thank CAPES-Brazil - CAPES-PROEX-23038.000625/20219-68 and CNPq-Brazil - Grant number 3110774/2019-5 - for the financial support.

Conflicts of Interest: The authors declare that they have no conflict of interest in the publication.

\section{REFERENCES}

1. Fuller R. Probiotics in man and animals. J Appl Bacteriol. 1989;66:365-78.

2. Soccol CR, Vandenberghe LPS, Spier MR, Medeiros, ABP, Yamaguishi CT, Lindner JD, et al. The Potential of Probiotics: A Review. Food Techol Biotech. 2010;48:413-34.

3. Fujiya M, Kohgo Y. Novel perspectives in probiotic treatment: the efficacy and unveiled mechanisms of the physiological functions. Clin J Gastroenterology. 2010;3:117-27.

4. Calder PC, Kew S. The immune system: a target for functional foods? Brit J Nutr. 2002;88:165-76. 
5. Oraby MM, Allababidy T, Ramadan EM. The bioavailability of selenium in Saccharomyces cerevisiae. Ann Agric Sci. 2015;60:307-15.

6. Czerucka D, Piche T, Rampal P. Review article: yeast as probiotics - Saccharomyces boulardii. Aliment Pharmacol Ther. 2007;26:767-78.

7. Yin $\mathrm{H}$, Chen Z, Gu Z, Han Y. Optimization of natural fermentative medium for selenium-enriched yeast by D optimal mixture design. LWT - Food Sci Technol. 2009;42:327-31.

8. World Health Organization. Vitamin and mineral requirements in human nutrition, 2nd ed. Bangkok, 2005. Available from: http://www.who.int/iris/handle/10665/42716.

9. Clark LC, Combs GFJr, Turnbull BW, Slate EH, Chalker DK, Chow J, et al. Effects of selenium supplementation for cancer prevention in patients with carcinoma of the skin. A randomized controlled trial, Nutritional Prevention of Cancer Study Group. J Am Med Assoc.1996;276:1957-63.

10. Lin Y, Ren Y, Zhang Y, Zhou J, Zhou F, Zhao Q, et al. Protective role of nano-selenium-enriched Bifidobacterium longum in delaying the onset of streptozotocin-induced diabetes. R Soc Open Sci. 2018;5:181156.

11. Puccinelli M, Malorgio F, Rosellini I, Pezzarossa B. Production of selenium-biofortified microgreens from seleniumenriched seeds of basil. J Sci Food Agric. 2019;99:5601-5.

12. Zarczynnska K, Sobiech P, Radwinska J, Reekawek W. Effects of selenium on animal health. J Elem s. 2013;32940.

13. Poursaeid N, Azadbakht A, Balali GR. Improvement of zinc bioaccumulation and biomass yield in the mycelia and fruiting bodies of Pleurotus florida cultured on liquid media. Appl Biochem Biotechnol. 2015;175:3387-96.

14. Dermici A, Pometto III A. Enhanced Organically Bound Selenium Yeast Production by Fed-Batch Fermentation. J Agric Food Chem. 1999;47:2496-500.

15. Pothoulakis C. Review article: anti-inflammatory mechanisms of action of Saccharomyces boulardii. Aliment Pharmacol Ther. 2009;30:826-33.

16. Im E, Pothoulakis C. Recent advances in Saccharomyces boulardii research. Gastroen Clin Biol. 2010;34:62-70.

17. Fietto JLR, Araújo RS, Valadão FN, Fietto LG, Brandão RL, Neves MJ, et al. Molecular and physiological comparisons between Saccharomyces cerevisiae 131 and Saccharomyces boulardii. Can J Microbiol. 2004;50: 615-21.

18. Buts, J-P. Twenty-Five Years of Research on Saccharomyces boulardii Trophic Effects: Updates and Perspectives. Dig Dis Sci. 2009;54:15-8.

19. Ponce de León CA, Bayón MM, Paquin C, Caruso JA. Selenium incorporation into Saccharomyces cerevisiae cells: a study of different incorporation methods. J Appl Microbiol. 2002;92:602-10.

20. Ouerdane L, Mester Z. Production and Characterization of Fully Selenomethionine-Labeled Saccharomyces Cerevisiae. J Agric Food Chem. 2008;56:11792-9.

21. Salmon DNX, Fendrich RC, Cruz MA, Montibeller VW, Vandenberghe LPS, Soccol CR, Spier MR. Bioprocess for phytase production by Ganoderma sp. MR-56 in different types of bioreactors through submerged cultivation. Biochem Eng J. 2016;114:288-97.

22. Alidee T, Habbal H, Tohla M. Optimization of selenium enriched Saccharomyces cerevisiae by Response Surface Methodology (RSM). Int J Chem Tech Res. 2016;9:221-6.

23. Sindhu R, Gnansounou E, Bonod P, Pandey A. Bioconversion of sugarcane crop residue for value added products, An overview. Renew Energ. 2016;98:203-15.

24. Pan NC, Pereira HCB, da Silva, MLC, Vasconcelos AFD, Celligoi MAPC. Improvement production of hyaluronic acid by Streptococcus zooepidemicus in sugarcane molasses. Appl Biochem Biotechnol. 2017;182(1):276-93.

25. Wang Z, Zhang L, Tan T. High cell density fermentation of Saccharomyces cerevisiae GS2 for selenium-enriched yeast production. Korean J Chem Eng. 2010;27:1836-40.

26. Koch AL. Growth measurement. In: Reddy CA, Beveridge TJ, Breznak JA, Marzluf GA, Schmidt TM, Snyder LR, editors. Methods for general and molecular microbiology. Washington, (D.C.): American Society for Microbiology Press; 2007 p. 172-199.

27. Dubois M, Gilles KA, Hamilton JK, Rebers PA, Smith F. Colorimetric method for determination of sugars and related substances. Anal Chem. 1956;28:350-6.

28. Miller GL. Use of dinitrosalicylic acid reagent for determination of reducing sugar. Anal Chem. 1959;31:426-8.

29. Mathew M, Narayana B. An easy spectrophotometric determination of selenium using azure $B$ as a chromogenic reagent. Indian J Chem Technol. 2006;13:455-8.

30. Miekeley N, Dias Carneiro MTW, Porto da Silveira CL. How reliable are human hair reference intervals for trace elements? Sci Total Environ. 1998;218:9-17.

31. Rajashree K, Muthukumar T. Preparation of Organic Selenium Yeast by Fed-Batch Fermentation. Intl J Food Ferment.Technol. 2013;3:135-42. 
32. Pardo S, Galvagno MÁ, Cerrutti P. Estudios de la viabilidad y la vitalidad frente al congelado de la levadura probiótica Saccharomyces boulardii: efecto del preacondicionamiento fisiológico. Rev Iberoam Micol. 2009;26:(2)155-60.

33. Trigueros DEG, Fiorese ML, Kroumov AD, Hinterholz CL, Nadai BL, Assunção GM. Medium optimization and kinetics modeling for the fermentation of hydrolyzed cheese whey permeate as a substrate for Saccharomyces cerevisiae var. boulardii. Biochem Eng J. 2016;110:71-83.

34. Zare $\mathrm{H}$, Owliac $\mathrm{P}$, Vahidia $\mathrm{H}$, Khujin $\mathrm{MH}$. Simultaneous optimization of the production of organic selenium and cell biomass in Saccharomyces cerevisiae by Plackett-Burman and Box-Behnken Design. IJPR. 2018;17:1081-1092.

35. Tuite MF, Oliver SG. Saccharomyces. Biotechnology Handbooks. vol. 4, Plenum Press, New York; 1991.

36. Volesky B, May-Phillips HA. Biosorption of heavy metals by Saccharomyces cerevisiae. Appl Microbiol Biotechnol. 1995;42:797-806.

37. Kieliszek M, Błażejak S, Piwowarek K. et al. Equilibrium modeling of selenium binding from aqueous solutions by Candida utilis ATCC 9950 yeasts. 3 Biotech 2018;8:388.

38. Suhajda A, Hegoczki J, Janzso B, Pais I, Vereczkey G. Preparation of selenium yeasts I. Preparation of seleniumenriched Saccharomyces cerevisiae. J Trace Elem Med Biol. 2000;14:43-7.

39. Rajashree K, Muthukumar T. Selection of culture medium and conditions for the production of selenium enriched Saccharomyces cerevisiae. Afr J Biotechnol. 2013;12(20):2972-7.

40. EFSA (European Food Safety Authority). Selenium-enriched yeast as source for selenium added for nutritional purposes in foods for particular nutritional uses and foods (including food supplements) for the general population. Scientific Opinion of the Panel on Food Additives, Flavourings, Processing Aids and Materials in Contact with Food. The EFSA J. 766, 1-42;2008. Available from: https://efsa.onlinelibrary.wiley.com/doi/epdf/10.2903/j.efsa.2008.766.

2021 by the authors. Submitted for possible open access publication under the terms and conditions of the Creative Commons Attribution (CC BY NC) license (https://creativecommons.org/licenses/by-nc/4.0/). 